\title{
The maternal interactive style in shared reading: Building a categorical evaluation system
}

\section{O estilo interativo materno na leitura compartilhada: construção de um sistema de avaliação por categorias}

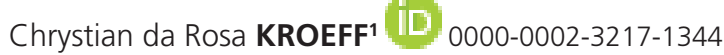 \\ Nicole Pandolfo SILVEIRA ${ }^{1}$ iD) 0000-0002-5387-6685 \\ Ana Paula KAFER ${ }^{1}$ iD 0000-0002-7007-078X \\ Denise Ruschel BANDEIRA' ${ }^{1}$ iD) 0000-0001-9867-2718
}

\begin{abstract}
The way of the mother's interaction with her child is called maternal interactive style. It has been studied in the context of shared reading. This study aimed to formulate a system of evaluation of the interactive style in shared reading through behavior categories. Categories were constructed from previous studies, and then empirically tested. Fifty-two dyads participated. The average age of the mothers was $35.70( \pm 6.13)$ years; the children's ages varied from 22 to 76 months (Mean $=48.59$; Standard Deviation $=17.88$ ). The dyads were filmed in a shared reading interaction. The videos were then analyzed. Agreement analyses (intraclass correlation coefficient) were made between observers in order to test the categories. Most of the categories presented good or excellent agreement, indicating that they were well constructed and properly described. We believe that the system may be useful in future studies investigating the relationship of the maternal interactive style in shared reading with other variables involved.
\end{abstract}

Keywords: Parent-child relations; Mother-child relations; Reading.

\section{Resumo}

O modo como a mãe interage com a criança é o estilo interativo materno, e vem sendo estudado no contexto de leitura compartilhada. Este trabalho buscou construir um sistema de avaliação do estilo interativo na leitura compartilhada, por

$\because \operatorname{cr}$

1 Universidade Federal do Rio Grande do Sul, Instituto de Psicologia, Programa de Pós-Graduação em Psicologia. R. Ramiro Barcelos, 2600, Sala 220, Santa Cecília, 90035-003, Porto Alegre, RS, Brasil. Correspondência para/Correspondence to: C.R. KROEFF. E-mail: <chrystiankroeff@gmail.com>.

Article based on the dissertation of C.R. KROEFF, entitled "O estilo interativo materno na leitura compartilhada: narratividade, práticas parentais e desenvolvimento infantil". Universidade Federal do Rio Grande do Sul, 2018.

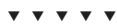

Como citar este artigo/How to cite this article

Kroeff, C. R., Silveira, N. P., Kafer, A. P., \& Bandeira, D. R. (2019). The maternal interactive style in shared reading: Building a categorical evaluation system. Estudos de Psicologia (Campinas), 36, el80151. http://dx.doi.org/10.1590/1982-0275201936e180151 
meio de categorias de comportamento. Categorias foram propostas a partir de trabalhos prévios e testadas empiricamente. Participaram do estudo 52 díades. As mães tinham em média 35,70 ( $\pm 6,13)$ anos; e as crianças, de 22 a 76 meses (Média = 48,59; Desvio Padrão = 17,88). As díades foram filmadas em interação de leitura, e os vídeos posteriormente analisados. Foram feitas análises de concordância (coeficientes de correlação intraclasse) entre observadores a fim de testar as categorias. A maioria das categorias apresentou concordância boa ou excelente, indicando serem bem construídas e descritas. Acredita-se que o sistema pode ser útil em trabalhos futuros que investiguem a relação do estilo interativo materno na leitura compartilhada com outros fatores.

Palavras-chave: Relação pai-criança; Relação mãe-filho; Leitura.

The maternal interactive style refers to the way the mother (or another adult who fulfills this role) interacts with her child. The kind of behavior they use, how the child engages in a given situation, and their characteristics as to the incentive and responsiveness to the other interaction agent (Cline \& Edwards, 2016; Vandermaas-Peeler, Sassine, Price, \& Brilhart, 2012). The mother is expected to enact elements of her general parenting practices at a specific and circumscribed time with the child. Therefore, the interactive style can provide a taste of how caregivers usually interact.

Social exchanges between adults and children have been studied in the context of child development. Flynn, Laland, Kendal, and Kendal (2013) highlight the tendency to look for models to understand the influence of the type of interaction between dyads on culture transfer - that is, lifestyles, in order to become an active member from the community. In a recent text, Keller (2018) took up the importance of subtleties in verbal communication between mother and child, as a manifestation of emotions and questions about mental states, desires and intentions, in promoting developmental trajectories, which are so varied, according to the cultural context.

A context of interaction is shared reading, especially in the family context, which can be considered as a parental practice aimed at reading children's books with their sons and daughters (Saracho, 2018). There is not only one way to follow a story with children, and the adult who mediates reading can use various strategies and behaviors throughout this specific interaction. Similarly, the child plays an active role at the same time, influencing the way narratives are enacted. Taken as a private meeting place for mothers, fathers and children, shared reading serves as a rich context in which adults express their own ways of being and staying together with their children. It is from this understanding that the concept of interactive style emerges, which will be performed at the moment when adult and child interact through a book.

The benefits of shared reading have been demonstrated by many authors, both theoretically and empirically (Velandia, 2014; Wasik, Hindman, \& Snell, 2016; Zauche, Thul, Mahoney, \& Stapel-Wax, 2016), and some studies have focused on the behaviors that are most used in these moments (Flores, Santos, Amadeu, \& Dias, 2013; Vandermaas-Peeler et al., 2012). Thus, research has not been limited to investigating the number of times parents read to their children; they have also questioned which practices may be most associated with positive outcomes in the language learning process, literacy and the development of other skills.

Due to the academic concern to study aspects of shared reading, as well as ways in which adults and children practice it, different proposals for evaluation and observation of this interaction can be found. It can be seen that the formats applied in shared reading analysis, for research purposes, vary mainly in terms of the nomenclature of observed practices - and not so much in the content itself - which will be demonstrated in the section of this article that describes the categories analyzed. Thus, the researchers of this study can list themes that are repeated, if not in all, in most of the publications consulted. Consequently, the objectives of this paper are to outline, organize and present a method of assessment and classification of behaviors that occur specifically at the time when an adult and a child practice shared reading. Before being unprecedented, these categories will be introduced in order to recreate and reorganize the themes already found in previous

2 studies. Their definitions will be further explored in the article. 


\section{Method}

\section{Part 1: Preparation of Categories and Coding Procedures}

\section{Analyzed categories}

The proposed categories were the result of consulting the literature of the area. The experience of observing and coding shared reading interaction also contributed to the elaboration and improvement of the categories. The evaluation proposal seeks to investigate how the mother reads with her son or daughter; and not the content. This means that the assessment is about how the adult conducts this reading. That is, the investigation falls into questions such as: does the mother seek to teach content to her child? Does she explain the elements that appear in the book? Does the mother encourage the child's participation in reading? Does the adult use everyday elements of their child to tell the story? Does the mother use different sounds and noises to tell the story? Questions like these refer to tools that characterize the shared reading moment; that give the outline for the interaction that occurs between adult and child. The researchers proposed six main categories to be observed in maternal behaviors, which consist of teaching, invitation, reinforcement, modulation, connection, and narration.

The Teaching category refers to all behavior delivered by a mother who seeks to teach, explain or leverage the elements contained in the book to stimulate the child's learning. Corrections and descriptions fall into this same category. Teaching behaviors can be observed in interactions about words, sounds, animal names, colors, among others. This category refers to times when the adult explains (gives, delivers) the content to the child, but not in asking about the examples cited above - this kind of behavior would be classified in the next category.

This category is considered as identifying and/or naming colors, activities, objects, people, and other elements that arise throughout reading by authors such as Bus, Belsky, van-IJzendoorn, and Crnic (1997), Deckner, Adamson, and Bakeman (2006), Dexter and Stacks, (2014), Flores et al. (2013), and Hindman, Connor, Jewkes, and Morrison (2008). Also included are corrective and instructional practices regarding children's attitudes, which is present in the works of Bus et al. (1997), Cline and Edwards (2016), DeBaryshe (1995) and Flores et al. (2013). Still, activities such as explanations, summaries and definitions, included in the categorization of Flores et al. (2013), Hindman et al. (2008) and Vandermaas-Peeler et al. (2012), and favoring learning through paused reading or introduction to words (Deckner et al., 2006; Dexter \& Stacks, 2014) are included in the Teaching category. According to Landry et al. (2012), these are behaviors that provide cognitive and linguistic support to the child.

The mother's attitudes toward engaging the child in reading are classified in the Invitation category. This is used at times when the adult calls for reading, which can occur either by drawing the child's attention to some element of the book (e.g., "check this out!"), Or by asking a question about something specific (such as "what do you think he [the character] is thinking about that?"). Both fulfill the role of attracting the child's focus to the reading interaction. It is common for mothers to also employ predictive questions about history, also understood here as a way of engaging the child through interaction (e.g., "what do you think it's going to happen?").

The primary ways of invitation present in other studies in the area consist of: drawing attention to the text, image or content, a behavior discussed in Aram and Shapira (2012), Bus et al. (1997), Deckner et al. (2006), Dexter and Stacks (2014) and Flores et al. (2013); and through questions, also considered by Bus et al. (1997), Cline and Edwards (2016), DeBaryshe (1995), Deckner et al. (2006), Flores et al. (2013) and Hindman et al. (2008). Solicitations, such as requests for the child to repeat something or to numerically 
tell some element of the story, can also configure ways to summon the child to interact with the book (Vandermaas-Peeler, Nelson, Bumpass, \& Sassine, 2009; Vandermaas-Peeler et al., 2012).

The reinforcement category refers to the mother's behaviors that, in a way, reward and encourage the child's attitudes during reading. They usually appear in the form of compliments and answers indicating a correct answer. These are comments that encourage the child to continue in the activity, and risk new ways to explore the elements that the book brings. Another type of behavior that serves to reward the child's engagement is the repetition that the mother makes from a child's speech or action, since it signals that what the child has just done was appropriate.

This category was elaborated through the description, in previous studies, of behaviors that serve as motivation and encouragement for the child. This is commonly referred to as praise, encouragement, positive feedback or motivation (Bus et al., 1997; Cline \& Edwards, 2016; Flores et al., 2013; Landry et al., 2012; Vandermaas-Peeler et al., 2009). Also, it is possible to perceive attitudes such as the repetition or amplification of the child's speech (DeBaryshe, 1995; Deckner et al., 2006; Flores et al., 2013), which are used to evaluate the same type of interaction, i.e., the ones responsively encouraging engagement in shared reading.

There is also the category connection, which refers to the mother's comments that try to relate what appears in the book with some element of the child's life story. These are behaviors that expand the reading experience and thus favor the establishment of connections between the narrative of the book and the narrative that the child has been building from their experiences. It is common to classify the mother's comments about playground trips, television shows, visiting a family member, school events, playing with friends, and previous readings as connections. Links made by the mother between the story presented in the book and the child's personal characteristics are also classified under the category connection.

Several examples of behaviors of this kind can be found in the literature, with different names, such as: expansion (DeBaryshe, 1995); insertion (Flores et al., 2013); comments on external elements (Bus et al., 1997); and "building bridges" (Vandermaas-Peeler et al., 2009); besides the very term "connection" (Aram \& Shapira, 2012; Hindman et al., 2008). The latter was used in the present study because it is believed to represent the desired goal for this category more clearly (in the sense that it "connects" what emerges during shared reading with the child's own reports regarding his or her daily life).

Throughout this research, other behaviors were noticed, which could distinguish important differences in the interactive style of mothers. Thus, two new categories were included in the study: modulation and narration. A study that investigated the verbal behavior of storytellers in a pediatric hospital also identified the presence of these two categories, naming them "dramatizing" and "storytelling," respectively (Flores et al., 2013).

Modulation is a category into which behaviors that signal important variations in tone or rhythm of reading are classified. Through interjections, laughter, and imitation of noises, grunts or animal sounds, the mother inserts a greater range of emotional variation into the interaction. They thus explore the prosodic features of the language. Although rarer, this kind of attitude can also be observed in more exaggerated motor enactments, such as spreading arms like a monster or making a face that relates to what is going on in the book. Modulation behaviors, therefore, consist of paralinguistic features as they accompany and enhance the speech experience.

Finally, it is noteworthy that the narration category includes those behaviors used only to describe the story that goes on in the book. Thus, they do not refer to interventions used to teach, reinforce or summon the child. The narration described here is usually observed in statements containing action verbs, since they 4 simply narrate what is happening on the pages. Thus, it is possible to say that this type of interaction has 
less authorial material from the adult who mediates reading, since this adult relies more on the specifics of the story.

The categories were formed according to the latent objectives that these behaviors would have. Therefore, some of the mother's attitudes may seem different in some ways, such as a sentence being a question or not, for example. However, when these behaviors, whether consisting of an adult questioning or an exclamation, seem to have the same purpose, they are classified in the same category.

An example of this situation would be the mother saying, during reading, something like "do you know this animal here?" and, soon after, "read this here with me!". There are many differences between these two vocalizations. In addition to being a question or not, there is also the content, which in the first line draws attention to one element of the book and which in the second one explicitly calls for interaction. Here it is important to remember that the content of the reading interaction will not be evaluated in this study. Another difference is the immediate purpose of these statements: to ask about the animal in the first sentence, and to order the child to read something with the mother in the second one. In a broader sense, however, both verbal behaviors have the same latent objective of inviting, engaging, attracting the child's attention and interest to shared reading or to elements presented by the book. The formal resources used by the mother during the interaction, therefore, are categorized according to this type of objective.

\section{Interaction observation and coding instructions}

The observation of interactive style during reading was systematized through the methodological procedures presented by Fagundes (2015), and Moura and Ribas (2007), authors who presented guidelines for performing systematic observations. First, it is necessary to define a criterion that clarifies whether or not reading interaction is occurring - that is, how do you know when coding begins? Reading begins before the book is opened. The book object itself already provides opportunities for exchanges between mother and child, with its format, the material it is made of, the colors, the cover illustration, the title, and any other graphic signs on it. Thus, the criterion to begin coding is the presence of the first use of the book as an object of exchange between the dyad. There can be expressions like "look, a book!", or "let's read a little bit?" So, there should still be no coded moments when only the mother handles the book without the child's participation (understood here as any focus of attention towards this activity, from a more active one, such as picking up the book, to an even more passive one, such as staring at it).

Secondly, the criterion to stop coding is also necessary, that is, to observe the output of the shared read interaction. A closed book after reading can elicit behaviors that can still be classified as products of reading interaction. In addition to elements of the back cover, such as illustrations, texts and colors, the content of what happened in history may continue to reverberate in the exchanges of the dyad. Comments such as "what did you think of the book?", or "which part did you like the most?". Thus, the end of the shared reading evaluation occurs when the book leaves the scene (it is put back in the shelf, or simply put aside) and when the dyad departs for another task or a new dialogue - the book is no longer the eliciting object of social exchanges between the Mother and the child.

Finally, there is a need to define when considering the beginning and the end of a single code. The researcher who evaluates the interaction needs pre-established criteria to know when to consider, for example, a long speech by the mother as a unique behavior - thus adding just one point in a specific category - or as a succession of different behaviors - which would give the mother several extra points. Defining these criteria is about establishing which unit of analysis to be considered. Thus, any behavior that can be interpreted as communicative in its entirety serves as the unit of analysis and is therefore coded as one point in one of the categories. The unit of analysis is then a behavior of the mother that can receive a unique coding. Such 
behaviors are usually preceded by an action by the child or a previous intervention of the mother that has already been coded. This second situation requires more attention from the observer, since a longer speech from the mother may encompass different codes, whether or not in the same category.

So, how can one know when to consider a new passage to be coded? Taking as an example the speech "there is a mask; the mask has those little holes, which represent the eyes", it is possible to count two codes. The first concerns the excerpt "there is a mask" in which the mother is naming an element that appears in the book. The second refers to "the mask has those little holes, which represent the eyes", in which the adult is explaining the characteristics of the object in question. Thus, the observer must account for two different behaviors. It is important to note that in this case both sections marked as separate would be coded into the Teaching category. This mother would thus receive a higher score in this category than another mother that only named the object or another that only described their function, for example.

The criterion to be applied to the analysis unit to be coded is any behavior, whether linguistic or gestural, that can be given a unique code in the assessment of interaction provides a clearer notion of when to consider it a new behavior or not. A behavior that is not clear enough to count as an occurrence - such as a piece of phrase, an incomplete speech or an unfinished gesture - should not be coded. Just as a long intervention by the mother should probably be evaluated as different events and therefore "divided" into different sections, each with its own coding. One can take the mother's speech used earlier as an example ("there is a mask; the mask has those little holes, that represent the eyes") to illustrate this issue. Note that only the "there" section does not configure a single code, and the entire first part of the sentence is required for the accurate coding ("there is a mask" as a teaching behavior). In addition, an observer who ignored the rest of this behavior could erroneously encode speech "there" as an invitation to read. On the other hand, using the entire sequence as a code would also be misleading since at least two distinct behaviors are contained in it: naming and explaining. As previously explained, from this speech, two points are accounted for in the Teaching category.

In Table 1, examples of behaviors to be coded in each category are shown. The excerpts used to illustrate behaviors emerged from observations made with mothers and children during the reading interaction.

Table 1

List of categories and exemplification of behaviors to be coded

\begin{tabular}{ll}
\hline Category & Behavioral examples \\
\hline Teaching & To correct ("shiver" after the child says "shaver"; "they weren't really monsters"; "there is a mask"); To name ("you \\
& and the ...?"; "These are the monsters"; "there is a chest here"; "the bogeyman"); To explain ("it's a book!"; "A \\
& little hole to see what's there, look"; "because he's curious"; "when he closes it, he doesn't see who will open it"); \\
& To linguistically stimulate ("pre ... ci ... ous!"; Point out word or letter to be read); To characterize ("the mask has little \\
& holes which represent the eyes"). \\
& To draw the child's attention ("What's this here?"; "Oh, here"; "look at this, curious little one!"; "Look at the chil- \\
& dren!"); To invite ("let's read?"; "Do you want mom to read or do you want to read?"); To create expectation ("what \\
& will happen?"; "Was it Zuza and Archimedes?"); To encourage ("see? It's cool"; "so..."; "and then...?"; "Opened \\
& the chest and...?"); To point out (usually accompanied by "look here" or "hey"); To guide ("what came up there?"; \\
& "And what happened?"; "You have to read the book"; "let's see this"); To invite an opinion ("what do you think?"). \\
Reinforcement & To praise ("very well!"; "Great"; "how nice!"); To nod ("uh-huh"; "ok"; "yeah"; "that's right"); To repeat (words, \\
& expressions, syllables, grimaces, etc.). \\
Connection & Relating to activities; Relating to events; Relating to specific objects; Relating to pop culture characters; Relating to the \\
& child's own characteristics. \\
& Emotional expressions ("I'm scared!";); Interjections ("huh"; "ooh"); Onomatopoeia ("brrr"); Sound effects ("tada!"); \\
Laughter. & Storytelling; Description of what is happening in the book; Predictions about the story being told; Opinions.
\end{tabular}




\section{Procedures}

These collections were performed indoors with as little noise as possible. Filming took place at the premises of the institutions of early childhood education, at rooms available at the Hospital de Clínicas (Clinical Hospital) of the city of Porto Alegre, and at the Centro Interdisciplinar de Pesquisa e Atenção à Saúde da Universidade Federal do Rio Grande do Sul (CIPAS-UFRGS, Interdisciplinary Center for Research and Health Care of the Federal University of Rio Grande do Sul). The rooms used in this study had between three and five square meters of area. During the interaction, only the mother and the child remained in the room. The area intended for interaction was demarcated with a rug measuring about two meters long and ninety centimeters wide.

At the moment of interaction, which was recorded on video, the mother and the child engaged in a shared reading moment with a literary book and, later, in an interaction with toys (for the present study, only the behaviors in the interaction mediated by the book were analyzed). Before beginning the recording, it was explained to the dyad that a bag with a book would be delivered, and that both should spontaneously explore the object, as if they were in a moment of their everyday interaction. No detailed instructions were given on how the mother should behave - she was instructed to read the book together with her child. In the three-observer video analysis stage, the shared reading interaction was only considered closed when both the mother and the child were no longer interacting through the book (reading, viewing the pictures, or even commenting on the story). Usually this was observed when the dyad went to other bags to explore the toys.

The observation technique was through the registration of the events, which consisted on counting the times in which such behavior - previously defined and conceptualized - was observed. The coding used was unique, so everything the observers considered as a unit of behavior needed to be coded in a single category. If it seemed possible that some behavior could fall into more than one category, the most relevant classification was considered, that is, with the most apparent, immediate latent objective. The assessment was not exhaustive, that is, not the entire interaction period was categorized. Observers only assessed behaviors that occurred within episodes of interaction in shared reading - through the book. It was common for the mother or the child to disconnect from this type of exchange for some time, and interventions that occurred at these intervals were not considered in the event log.

When linguistic and gestural behavior occurred at the same time and could refer to the same category, they were considered as a single event. For example, it is common for the mother to refer to some element of the book by saying "what is this here?" While pointing to the drawing referred to. It is understood that this whole behavioral orchestra concerns a single intentionality, so it must be coded as a singular event, and nothing else. Thus, it is avoided that the assessment of the mother's interactive style during reading has duplicate scores for the same moment of interaction.

\section{Part 2: Characterization of sample, materials used and analyses performed}

\section{Participants}

Fifty-two dyads composed of mother and child participated in the study. Participants were recruited from early childhood education institutions in the city of Porto Alegre, Brazil, and in a cohort study conducted at the Hospital de Clínicas of the city of Porto Alegre by the Núcleo de Estudos da Saúde da Criança e do Adolescente (NESCA, Center for Child and Adolescent Health Studies). The mothers' ages ranged from 23 to 48 years, with an average of $35.70(S D=6.13)$ years of age. They were evenly divided between the different levels of education, since $25.5 \%$ of them had completed elementary school, $17.6 \%$ had completed high 
school, $27.5 \%$ had finished higher education, and $29.4 \%$ of them had a postgraduate degree. As for family income, the distribution was as follows: $39.6 \%$ of them earned up to two minimum wages (BRL 1.996,00/ USD 482.00; date of conversion: 8/26/2019); 8.4\% earned between two and four minimum wages (BRL 1.996,00 - BRL 3.992,00/ USD 482 - USD 964.00; date of conversion: 8/26/2019); 35.4\% had an income between four and ten minimum wages (BRL 3.992,00 - BRL 9.980,00/ USD 964.00 - USD 2,410.00; date of conversion: 8/26/2019); and 16.7\%, over ten minimum wages (BRL 9.980,00/ USD 2,410.00; date of conversion: 8/26/2019). The children were between 16 and 72 months old, with a mean of 48.59 months of age $(S D=17.88$ ), and two of them were adoptive (one had been adopted at 5 months old and data collection was performed when the child was 2 years and 5 months old; the other had been adopted at 3 years old, having 5 years in data collection for this study). Of all children, 29 were girls (55.8\%) and 23 were boys $(44.2 \%)$. When asked how often they read with their children, $4.7 \%$ of the mothers said they never did, $11.6 \%$ said that rarely did, $30.2 \%$ said that they read once a week, 32.6\% answered a few days a week, and, finally, $20.9 \%$ reported reading every day with their son or daughter. No child was fully literate, although some were more familiar with letters and words. As for the observers who performed the video interaction analysis, they consisted of three researchers, one of whom was a trained psychologist and two undergraduate psychology students. They were all trained according to the procedures described in this article.

\section{Materials used}

\section{Sociodemographic Questionnaire}

A questionnaire was applied to collect the sociodemographic information described in the previous section, with these being the mother's age, the child's age, the mother's educational level, the child's sex, the family income and the frequency with which the dyad shared the reading of a book during the week. The mother's age was counted in years; the child's age, in months. The mother's educational level was collected using the last grade/year she had completed. The family income was collected according to minimum wage ranges. The frequency of reading between mother and child was collected through the following question: "how often do you read to your child?". The response options were "never", "rarely", "once a week", "a few days a week" and "every day".

\section{The book}

The book used in the research was "Zuza e Arquimedes" (Zuza and Arquimedes), by writer and illustrator Furnari (2007). The choice sought to consider a book whose language was accessible to different educational levels, enabling any participant to read the book with the child. In addition, the narrative is mostly told through images, encouraging the mother to use expressions made by the author in the storytelling. Even so, there is a small piece of text at the beginning of the book, which allows us to analyze how the adult explores written words with the child.

"Zuza e Arquimedes" has been awarded the highly commendable seal of the Fundação Nacional do Livro Infantil e Juvenil (FNLIJ, National Children and Youth Book Foundation), which is the Brazilian section of the International Board on Books for Young People (IBBY) and one of the leading agencies for children and youth literature in the country. Furnari's book tells the story of two children who fantasize and hide to surprise people who pass them by, working with doses of humor and suspense. It is a narrative that, although with some similar scenes throughout the events, provides a variation of characters, emotions and situations

8 to be explored by the adult who mediates the reading process. 
The agreement between different observers was assessed at three time points. The first was during the training, made with five videos of a pilot study. Observers coded each interaction between the dyad independently, and then the scores assigned by each of them were compared. The criterion of at least $70 \%$ agreement was used to consider them able to evaluate the videos of the empirical study (Fagundes, 2015; Moura \& Ribas, 2007). This value was calculated as follows: the sum between the sum of the agreements divided by the total of the accounted behaviors (i.e., the sum between all of the agreements and the total value of disagreements), and then multiplied by one hundred. Mathematically expressed, this formula would be:

(Sagreements)

( agreements + Edisagreements) $\times 100$

The second moment occurred throughout the video coding process, in which observers gathered to compare their scores. Following the previous criterion, where coding differed in any of the categories by more than $70 \%$ of the total number of observed behaviors, the evaluations were repeated independently and compared again. In most cases, a reevaluation was enough to achieve the desired level of agreement. There were three videos that required the evaluation of a third observer.

Finally, the third moment was a statistical analysis of the final scores attributed by the observers. To calculate the agreement in the assessment of shared reading, Intraclass Correlation Coefficients (ICC) were used (Koo \& Li, 2016). The model applied was the two-way mixed-effect model, since the objective of the analysis was to evaluate the agreement between a specific group of judges (observers) who evaluated the sample. In addition, it was decided to investigate the absolute-agreement rather than consistency, as observers should have the same scores for the same subjects, not the same mean value for the evaluated group.

\section{Ethical considerations}

This study was developed as part of the project entitled "Facilitating Parenting Practices in Early Childhood and their Associations with Child Development", which was approved by the Research Ethics Committee of the Institute of Psychology, CAAE Protocol No. 67131017.3.0000.5334. The procedures of the present research presented minimal risk to the participants. The legal guardians who participated in the study signed an informed consent form.

\section{Results}

Table 2 shows the ICC values for each shared reading variable, as well as the $95 \%$ confidence intervals and statistical significance. It was decided to include only the indices referring to the single measure, since it aims to evaluate the individual reliability of the observer, and not the reliability of the average values of the three observers.

Most ICCs showed values that can be considered good to excellent, being above 0.80 (Koo \& Li, 2016). The connection category was the only one below this classification, showing moderate agreement (yet it remained above 0.70). In addition, all indexes presented adequate statistical significance $(p<0.001)$. The categories Reinforcement and Modulation presented the highest agreements and could be classified as excellent, and all values within the confidence intervals (95\%) were good to excellent. The same could be observed with the total count of behaviors. The invitation category presented a good ICC value, as well as a confidence interval with values ranging from good to excellent. In turn, the teaching and narration categories, although showing good ICCs, presented a confidence interval (95\%) with values ranging from moderate to excellent. 
Agreement values and confidence intervals for analysis between shared reading judges $(n=52)$

\begin{tabular}{|c|c|c|c|c|c|c|c|}
\hline \multirow{2}{*}{ Category } & \multirow{2}{*}{ ICC } & \multicolumn{2}{|c|}{ Confidence interval (95\%) } & \multicolumn{4}{|c|}{ "F" test for null hypothesis } \\
\hline & & Lower limit & Upper limit & " $F$ " value & $d f 1$ & $d f 2$ & $p$ \\
\hline \multicolumn{8}{|l|}{ Teaching } \\
\hline Single measure & 0.845 & 0.745 & 0.908 & 11.752 & 51 & 51 & 0.001 \\
\hline \multicolumn{8}{|l|}{ Invitation } \\
\hline Single measure & 0.849 & 0.751 & 0.910 & 12.133 & 51 & 51 & 0.001 \\
\hline \multicolumn{8}{|l|}{ Reinforcement } \\
\hline Single measure & 0.912 & 0.852 & 0.949 & 22.395 & 51 & 51 & 0.001 \\
\hline \multicolumn{8}{|l|}{ Connection } \\
\hline Single measure & 0.715 & 0.550 & 0.826 & 5.923 & 51 & 51 & 0.001 \\
\hline \multicolumn{8}{|l|}{ Modulation } \\
\hline Single measure & 0.917 & 0.861 & 0.952 & 22.880 & 51 & 51 & 0.001 \\
\hline \multicolumn{8}{|l|}{ Narration } \\
\hline Single measure & 0.831 & 0.723 & 0.899 & 10.650 & 51 & 51 & 0.001 \\
\hline \multicolumn{8}{|l|}{ Total } \\
\hline Single measure & 0.917 & 0.860 & 0.951 & 22.989 & 51 & 51 & 0.001 \\
\hline
\end{tabular}

Note: ICC: interpretation criteria as described by Koo \& Li (2016): poor: up to 0.50 ; moderate: 0.50 to 0.75 ; good: 0.75 to 0.90 ; excellent: above 0.90 . ICC: Intraclass Correlation Coefficient; $p$ : Level of Statistical Significance.

\section{Discussion}

This paper presented categories for the assessment of the maternal interactive style during a shared reading interaction. The categorization was constructed based on previous studies, as well as additions due to the contact with the interaction recordings. To investigate whether the categories were well described, the system was tested by agreement between different observers. The results indicated that different observers achieved good levels of agreement, which supports the quality of the conceptual and behavioral definitions of the categories. Thus, it is possible to state that the categories described here can be a useful tool in the evaluation of interactions during a shared reading.

Specifically regarding the categories, the researchers of this study highlight the reduced agreement value of the connection category, which may be related to the low number of times that mothers presented behaviors of this nature. Thus, a small disagreement has a greater weight in terms of percentage - for example, if one observer counts 1 event, while another claims to have observed 2, both agreed on only $50 \%$ of the analysis, even with only one point of difference. Vandermaas-Peeler et al. (2012) investigated the interactive style of fathers and mothers during a shared reading interaction and, in addition to finding a low frequency for the connection maternal behavior, found no significant associations with other investigated variables, such as the sex of the child or parent. In DeBaryshe's (1995) study, similarly, these behaviors were the least frequent. Flores et al. (2013), in turn, identified a greater use of this category, and statements that encouraged the child to relate the story with their own content were the most used ones. However, the study in question evaluated the verbal behavior of storytellers in a pediatric hospital rather than the verbal behaviors of parental figures.

The other categories, however, proved satisfactorily adequate. This finding is in line with trends presented by more recent studies (Fleury \& Hugh, 2018; Han \& Neuharth-Pritchett, 2014), which have been working with similar behaviors in shared reading interactions, although with different names. Ramos 
and Salomão (2016), for example, performed a longitudinal study with caregivers of children who were evaluated at 24, 30 and 36 months of age, and observed their feedback, solicitation and directive behavior practices. Their definitions are analogous to what has been called here reinforcement, invitation, and teaching, respectively.

A University of Miami study specifically evaluated the work of teachers with words while reading with preschool children aged three to five (Lipsky \& Adelman, 2016). The authors found results that showed an interactive style described in a similar way to the present research, even with the focus of the evaluation being only the use of words in the book. Their teaching practices, their ability to connect students with previous experiences, to invite them for reading engagement, and asking to define terms were observed. Through these studies, it is possible that both mothers and educators exhibit similar behaviors, but they may vary in the amount with which each practice will be most used.

Finally, it is believed that future studies may draw on the assessment scheme presented here and tested to study the maternal interactive style during a shared reading interaction. This research, which presents guidelines for coding categories in this field, is unprecedented in the country. Future research prospects should explore the relationships between dyad characteristics such as age and socioeconomic status, and behaviors presented in the interaction. In addition, as discussed by Flynn et al. (2013) and Keller (2018), studies that aim to observe characteristics of the interaction between caregivers and children can contribute to studies on the developmental aspects of children.

\section{Contributors}

C.R. KROEFF, research conception and design, data collection, analysis and interpretation, elaborating the article, and for the review and approval of the final version of it. N.P. SILVEIRA and A.P. KAFER, data collection, analysis and interpretation, and for the review and approval of the final version of the article. D.R. BANDEIRA, research conception and design, data analysis and interpretation, and for the review and approval of the final version of the article.

\section{References}

Aram, D., \& Shapira, R. (2012). Parent-child shared book reading and children's language, literacy, and empathy development. Rivista Italiana Di Educazione Familiare, 2, 55-65.

Bus, A. G., Belsky, J., van-IJzendoorn, M. H., \& Crnic, K. (1997). Attachment and bookreading patterns: A study of mothers, fathers, and their toddlers. Early Childhood Research Quarterly, 12, 81-98. http://dx.doi.org/10.1016/ S0885-2006(97)90044-2

Cline, K. D., \& Edwards, C. P. (2016). Parent-child book-reading styles, emotional quality, and changes in early head start children's cognitive scores. Early Education and Development, 28(1), 1-18. http://dx.doi.org/10.1080/104092 89.2016.1177392

DeBaryshe, B. D. (1995). Maternal belief systems: Linchpin in the home reading process. Journal of Applied Developmental Psychology, 16(1), 1-20. http://dx.doi.org/10.1016/0193-3973(95)90013-6

Deckner, D. F., Adamson, L. B., \& Bakeman, R. (2006). Child and maternal contributions to shared reading: Effects on language and literacy development. Journal of Applied Developmental Psychology, 27(1), 31-41. http://dx.doi. org/10.1016/j.appdev.2005.12.001

Dexter, C. A., \& Stacks, A. M. (2014). A preliminary investigation of the relationship between parenting, parent-child shared reading practices, and child development in low-income families. Journal of Research in Childhood Education, 28(3), 394-410. http://dx.doi.org/10.1080/02568543.2014.913278

Fagundes, A. J. D. F. M. (2015). Descrição, definição e registro de comportamento (17th ed.). São Paulo: Edicon.

Fleury, V. P., \& Hugh, M. L. (2018). Exploring engagement in shared reading activities between children with autism spectrum disorder and their caregivers. Journal of Autism and Developmental Disorders, 48(10), 3596-3607. http:// dx.doi.org/10.1007/s10803-018-3632-8 
Flores, E. P., Santos, G. F. A., Amadeu, L. F. M., \& Dias, A. R. (2013). Leitura compartilhada em um hospital pediátrico: análise do comportamento verbal dos contadores. Psicologia: Reflexão e Crítica, 26(4), 711-720. http://dx.doi. org/10.1590/S0102-79722013000400011

Flynn, E. G., Laland, K. N., Kendal, R. L., \& Kendal, J. R. (2013). Developmental niche construction. Developmental Science, 16(2), 296-313. http://dx.doi.org/10.1111/desc.12030

Furnari, E. (2007). Zuza e Arquimedes (3rd ed.). São Paulo: Editora Paulinas.

Han, J., \& Neuharth-Pritchett, S. (2014). Parents' interactions with preschoolers during shared book reading: Three strategies for promoting quality interactions. Childhood Education, 90(1), 54-60. http://dx.doi.org/10.1080/00094 056.2014 .872516

Hindman, A. H., Connor, C. M., Jewkes, A. M., \& Morrison, F. J. (2008). Untangling the effects of shared book reading: Multiple factors and their associations with preschool literacy outcomes. Early Childhood Research Quarterly, 23(3),330-350. http://dx.doi.org/10.1016/j.ecresq.2008.01.005

Keller, H. (2018). Parenting and socioemotional development in infancy and early childhood. Developmental Review, 50, 31-41. http://dx.doi.org/10.1016/j.dr.2018.03.001

Koo, T. K., \& Li, M. Y. (2016). A Guideline of selecting and reporting intraclass correlation coefficients for reliability research. Journal of Chiropractic Medicine, 15(2), 155-163. http://dx.doi.org/10.1016/j.jcm.2016.02.012

Landry, S. H., Smith, K. E., Swank, P. R., Zucker, T., Crawford, A. D., \& Solari, E. F. (2012). The effects of a responsive parenting intervention on parent-child interactions during shared book reading. Developmental Psychology, 48(4), 969-986. http://dx.doi.org/10.1037/a0026400

Lipsky, M., \& Adelman, A. (2016). Preschool teachers' implementation of vocabulary strategies during shared reading: a comparative study. Early Education and Development, 27(7), 957-975. http://dx.doi.org/10.1080/10409289.201 5.1046785

Moura, M. L. S., \& Ribas, A. F. P. (2007). A Pesquisa observacional e o estudo da interação mãe-bebê. In C. A. Piccinnini, \& M. L. S. Moura (Eds.), Observando a interação pais-bebê-criança (1st ed., pp. 103-130). São Paulo: Casa do Psicólogo.

Ramos, D. D., \& Salomão, N. M. R. (2016). Estilos linguísticos de educadoras e habilidades sociocomunicativas infantis aos 24, 30 e 36 meses e contextos de leitura. Estudos de Psicologia, 33(3), 489-501. http://dx.doi.org/198202752016000300012

Saracho, O. N. (2018). The social practice of parents' storybook reading: A critical discourse analysis. Early Child Development and Care, 1-22. http://dx.doi.org/10.1080/03004430.2018.1498091

Vandermaas-Peeler, M., Nelson, J., Bumpass, C., \& Sassine, B. (2009). Social contexts of development: Parent-child interactions during reading and play. Journal of Early Childhood Literacy, 9(3), 295-317. http://dx.doi.org/10.11 77/1468798409345112

Vandermaas-Peeler, M., Sassine, B., Price, C., \& Brilhart, C. (2012). Mothers' and fathers' guidance behaviours during storybook reading. Journal of Early Childhood Literacy, 12(4), 415-442. http://dx.doi.org/10.1177/1468798411417381

Velandia, N. A. (2014). La lectura conjunta y la interacción entre adultos y niños de 3-5 años. Revisión de antecedentes. Panorama, 8(14), 33-46. Recuperado el junio 15, 2016, de http://www.researchgate.net/publication/282188846_ La_lectura_conjunta_y_la_interaccin_entre_adultos_y_nios_de_3-5_aos._Revisin_de_antecedentes

Wasik, B. A., Hindman, A. H., \& Snell, E. K. (2016). Book reading and vocabulary development: A systematic review. Early Childhood Research Quarterly, 37, 39-57. http://dx.doi.org/10.1016/j.ecresq.2016.04.003

Zauche, L. H., Thul, T. A., Mahoney, A. E. D., \& Stapel-Wax, J. L. (2016). Influence of language nutrition on children's language and cognitive development: An integrated review. Early Childhood Research Quarterly, 36, 318-333. http:// dx.doi.org/10.1016/j.ecresq.2016.01.015

Recebido: November 30, 2018

Versão final: July 5, 2019

Aprovado: September 2, 2019 